\title{
INTERNAL RATE OF RETURN ON INVESTMENT IN HigheR EDUCATION IN EUROPE
}

\author{
JANUSZ JABLONOWSKI*
}

\section{KEYWORDS}

higher education, internal rate of return, European Union, Mincer wage equation

\begin{abstract}
The study aims to update the well-settled issue in literature of rate of return on investment in higher education in Europe. The proposed approach slightly modifies the existing methodology based on the Mincer equation, using an updated set of data for the period 2014-2016 from the European Central Bank's 'Household Finance and Consumption Survey'. The results obtained, ranging between 13\% and 21\%, are higher compared to historical records for the years 1996-2013. As for the microeconometric estimates of the Mincer-type equation, they are sound and comparable, although showing higher margins in relation to the recent figures. Thus, they may suggest an increasing trend in valuation and importance of human capital based on high school degree, especially for the Central-Eastern European Union countries, resulting probably from rapid economic and cultural convergence.
\end{abstract}

JEL Codes: C83, I26, J24, O12

\section{INTRODUCTION}

The factor that enhances growth in semi-endogenous growth models is represented by the human capital, which is a factor endogenised via timing and resources spent on education by two sectors, in principle, education, and production sector (Rebelo, 1991). The human capital helps to diminish the effect

* SGH Warsaw School of Economics, Poland, Email: janusz.jablonowski@sgh.waw.pl ORCID: 0000-0001-5935-8515 
of decreasing physical capital. In fact, models applying human capital rely on the productivity of the education sector rather than on the number of teachers. Lucas's (1988) model implies 7-10\% endogenous growth rate, which is implausibly high compared to the actual rate of approximately $2 \%$. Both models stick to a basic assumption of this class, i.e. direct correlation between the rate of economic growth and the productivity of the education sector in the long term. The current study follows closely the theoretical approach of Rebelo (1991). In order to meet this theoretical approach, the internal rates of return on investment in higher education are considered. This approach refers directly to the alternative costs of schooling, regarded as forgone wages during the high school years. The historical record for the estimates of this rate show even higher values. If the study confirms rates of $>10 \%$, then it would be evidence for a significant mismatch between macroscale models and estimates based on micro-foundations. While the data on the 'Household Finance and Consumption Survey' (HFCS; 2014-2016) for the 2016 wave were released in March 2020 for use in general research, this study elaborates the latest survey statistics. Surprisingly, despite these new data, the estimates are nearly the same as in 2014. A summary of the previous estimates is elaborated in the Results section.

The study is structured as follows: after this Introduction, the methodology for the calculation of the internal rate of return (IRR) on investment in higher education is described, followed by the calibration. After the Conclusions section, the detailed data applied in the calculations are provided in the Appendix.

IRR on Investment in Education

The applied approach refers to a positive influence of education on the life cycle-salary path. The importance of the issue is well summarized by Dziechciarz (2015), who has divided the returns into a matrix of private/social and market/ non-market profits. This study concentrates on the private market part, which, according to this study, shall bring better employability, higher earnings, less unemployment, labour market flexibility and greater mobility. The expected private market RoR on investment in education is computed in this study using two different approaches: the first one is directly derived from the Mincer (1958) equation. The key issue for the latter case is to compute the IRR on investment in education, however, without the so-called Heckman correction for employability, which is derived using previous works (e.g. Dziechciarz-Duda \& Krol, 2012). Due to data constraints on the exact career length, this important extension has been abandoned.

The IRR is a workhorse among the financial indicators, used to measure the profitability of the given investment by considering the opportunity cost. The Organisation for Economic Co-operation and Development (OECD; 2018) uses the net present value (NPV), while the IRR is a bit more developed; however, both use the discount rate factor and the opportunity cost. The study applies the 
approaches of Romele (2013) and De la Fuente and Jimeno (2009) based on an initial methodology of cost/benefit analysis by Harmon et al. (2013). The choice of the IRR, which includes the NPV, stems from the life cycle or the overlapping generations model (OLG) component, which extends a single (labour) tax rate on the labour life-time profile that reflects the hump-shaped life cycle profile of earnings.

To start the analysis, the OECD method for the NPV computation is summarized below first:

$$
N P V=-c_{t} /(1+i)_{t}+\stackrel{\%}{b_{t}} R A-a-d /(1+i)_{t}
$$

where $c_{t}$ - costs at period $t, \stackrel{\%}{b}$ - benefits at period $t, d$-duration of studies, $a$ - age at the beginning of activity in the labour market and $R A$ - effective retirement age.

Costs are composed of the following items:

Foregone earnings + direct private expenditures - grants allocated + increased future taxes + lost transfers

Benefits are composed of the following benefits:

Increases in earnings + higher probability of being employed (unemployment effect, 1 minus unemployment rate applied to average annual salary).

The methodology of the IRR, i.e. $N P V=0$, uses both the IRR and the Mincerian equation. The Mincer equation takes the following form:

$$
\ln y_{s, x}=\ln y_{0}+\stackrel{\%}{*}+\stackrel{\%}{\beta_{1}} x+{ }^{\%} x_{2}^{2}
$$

where $y$ stands for the (log) gross salary with $s$ years of completed education, $\%$

$r$ is a rate of return for one of three International Standard Classification of Education (ISCED) categories of maximum achieved education levels and $x$ is a rate of return on market experience. The next two equations bring the calculations closer to the OLG component by adding, for instance the pension premium factor,

$\tilde{n}_{R}=\imath_{R}\left(1-\tau_{v}\right) R R(\Theta \Xi-v)$,

Where $\Theta$ means a wage premium for each year of tertiary education, , $\Xi$ means the 'survival' rate for new students, $v$ stands for the labour market experience premium $(x)$, with the discount factor on pension benefits, $l_{R}$, given by the following expression: 
$\iota_{R}=\frac{R}{R+g+v-\varpi} \frac{1-e^{-(R+g+v-\varpi)(L E-R A)}}{e^{R Y}-1}$.

Moreover,

$$
R=\stackrel{\%}{*}-\stackrel{\%}{-v}
$$

$Y=R A-A g e_{0}-\stackrel{\%}{l}$

with the marginal tax rate for a person in a reference group $\tau_{\Delta}$ given by Eq. (7):

$$
\tau_{\Delta}=e m p \tau^{e m p}+p_{\Delta} \tau^{u n}
$$

where $\tau_{v}$ is the marginal income tax rate for pensioners, $g$ indicates the growth in labour productivity over the past decade, $\varpi$ is the real growth rate of pensions, $L E$ denotes the life expectancy at birth and $R R$ represents the pension benefit replacement rate. Further, $p$ indicates the employment probability for people with upper secondary education, $Y$ is the length of the working period, ${ }^{1} A g e_{0}$ is the age at which school education starts, $l$ is the length of schooling and emp denotes the probability of becoming employed in the case of a tertiary educationlevel graduate $(I S C E D=5)$. The following equations approach the ultimate goal of the IRR, where $O P P C$ means the opportunity cost of schooling, and DIRC is the direct cost of schooling:

$$
O P P C=\stackrel{\%}{p}(1-\tau)
$$

$$
D I R C=P c e^{\%} e^{(v / 2)}
$$

where the direct private cost of tertiary education $P c$ is expressed as a percentage of the average wage of an upper secondary degree holder, $\tau_{\Delta}$ means the marginal tax factor for a person of the reference group, defined as a 'weighted' average of the marginal tax rate on labour earnings and the marginal tax rate on unemployment benefits, with weights given by the employment and unemployment probabilities. Finally, the IRR can be computed as follows:

1 A comparison with the secondary education graduates marked as $Y_{0}$, reported in the Appendix, shows a mixed correlation between the length of service with respect to completed education level, i.e. secondary school graduates report sometimes longer, but often shorter, average career paths. These figures are not taken directly here into computations. 


$$
I R R=\frac{\Theta_{n}+P_{n}+\tilde{n}_{R}}{O P P C+D I R C}
$$

with

$$
\Theta_{n}=\stackrel{\%}{p}\left(1-\tau_{\Delta}\right)(\Theta \Xi-v)
$$

where $P_{n}=\bar{y} p_{s e c} \Xi$, with $\bar{y}=1-\tau$ representing the net income. $p_{\text {sec }}=p_{h i} / \stackrel{\%}{p}-1$, where $p_{\text {sec }}$ means the average employment rate by secondary education level (ISCED 3-4), aged 25-64 years, $p_{h i}$ is the average employment rate of higher education-level student (ISCED 5-6), aged 25-64 years. Furthermore, the survival rate takes the form $\Xi=\left(n e w_{s t}-\right.$ awarded $\left._{s t}\right) / n e w_{s t}$, where the suffix $s t$ means the corresponding number of students. Consequently, $p$ means the employment probability for people with upper secondary education.

\section{Calibrating the IRR on Higher Education}

The calibration of the above-described formulas relies in principle on the OECD data, particularly gross and net replacement rates for employed and unemployed persons, employment and unemployment rates, employment rate data by educational attainment, probability to achieve the degree based on graduation rate data, marginal tax rates based on gross-gross labour tax rate (including employers' tax), factor productivity based on 10 years' average for gross domestic product (GDP) per hour worked at constant prices, pension growth dynamics (per head, at current prices and current purchasing power parities [PPPs], in US dollars; old age data, excluding survivors in public and mandatory private schemes); retirement age; gross and net replacement rates; life expectancy at birth; age of entry into school; average years of schooling (Wittgenstein Projection: mean years of schooling, age $25+$, total values); $\tau_{0}=\tau$ is taken as the average labour-time gross tax rate on earnings, taken from the progressivity tax model described by Jabłonowski (2018); thus, from the employee perspective, this excludes employers' labour tax burden. The average tax rate on unemployment earnings was taken from the OECD statistics, with their absent or apparently erroneous specification, as the minimum tax rate observed in the OECD tax/ benefit calculator. Both the rate of return on education $r s$ and the labour market experience $v$ were taken directly from the Mincer equation computed with the use of the standard ordinary least squares model based on the HFCS (2014-2016) 
country-specific data. ${ }^{2}$ As compared with the original settings of De La Fuente and Jimeno (2009) and Romele (2013), one category was computed differently, i.e. the cost of schooling $P c$, the direct private cost of tertiary education, expressed as a percentage of the average wage, was estimated according to the following formula:

$$
P \stackrel{\%}{c}=\stackrel{\%}{c_{s}} n_{s} / 12 / \bar{y} / l
$$

where $c_{s}$ represents the per-student overall annual expenditures based on OECD data $^{3} ; n_{s}$ stands for the overall number of students on the entire tertiary level, all categories, including public, private and international organizations; $\bar{y}$ means the average net life-time labour salary computed for single-year-age cohorts estimated from the HFCS-based data, and $l$ means the labour force taken from the European Commission AMECO database. In principle, the formula attempts to estimate the proxy for the percentage of the average net salary in the economy that needs to be economized for an average cost of any studying. Compared with the original formula, which considers the private costs, this study assumes that, if the representative household's perspective is taken, the entire working population, including also lower levels of completed education, contribute to the cost of studies, which are covered either from taxes (the entire labour force, and in fact, also pensioners, if applicable) or from the voluntary university fees. Regardless of the form in which the cost is covered, it is earmarked then to a representative household. The applied modification follows the so-called 'social' costs of schooling, which, contrarily to the 'private' costs, are spread over the entire society. Not going into the strengths and weaknesses of the methodology, which are summarized elsewhere (e.g. Psacharopoulos and Patrinos, 2002), the social costs tend to exhibit lower average values, as in the study by Montenegro and Patrinos (2013). The detailed parameters for each category are provided in the Appendix.

The discussion on the IRR methodology and the obtained results has a broad history in the literature. Although the issues of accumulation of human capital and its growth-spurring role are tempting, since the famous critique by Jones (2002), which pointed out that the so called $A K$ models $^{4}$ tend to generate $>10 \%$ growth rates, pure endogenous growth models are not common, and the growthstimulating role is rather considered in their semi-endogenous versions. It seems

2 The already-mentioned disclaimer on such an approach applies, i.e. the net income was available only for Italy and Poland.

3 Originally expressed in US dollars and thereafter converted to EUR with the average annual exchange rate of 0.7513 for the base year.

4 AK model is the simplest type of the endogenous growth model, known from the growth theory. It assumes the e.g. a constant level of technology. 
Table 1: Historical time series for the IRR (last column covers this study estimates)

\begin{tabular}{|l|l|l|l|l|l|l|l|l|l|l|}
\hline Countries $^{*}$ & $\mathbf{1 9 9 6}$ & $\mathbf{1 9 9 7}$ & $\mathbf{1 9 9 8}$ & $\mathbf{1 9 9 9}$ & $\mathbf{2 0 0 0}$ & $\mathbf{2 0 0 1}$ & $\mathbf{2 0 1 0}$ & $\mathbf{2 0 1 1}$ & $\mathbf{2 0 1 3}$ & $\begin{array}{l}\text { Average for } \\
\mathbf{2 0 1 4 - 2 0 1 6}\end{array}$ \\
\hline BE & 0.06 & 0.06 & 0.07 & 0.06 & 0.06 & 0.07 & - & 0.14 & 0.11 & $\mathbf{0 . 1 7}$ \\
\hline FI & 0.09 & 0.09 & 0.09 & 0.09 & 0.09 & 0.09 & - & 0.06 & 0.11 & $\mathbf{0 . 1 8}$ \\
\hline LU & 0.12 & 0.11 & 0.10 & 0.11 & 0.11 & 0.10 & 0.10 & 0.12 & - & $\mathbf{0 . 1 8}$ \\
\hline GR & 0.05 & 0.05 & 0.06 & 0.05 & 0.05 & 0.05 & 0.06 & 0.12 & 0.08 & $\mathbf{0 . 1 8}$ \\
\hline IE & 0.07 & 0.08 & 0.11 & 0.10 & 0.09 & 0.09 & 0.15 & 0.11 & 0.17 & $\mathbf{0 . 2 1}$ \\
\hline MT & - & - & - & - & - & - & - & 0.11 & & $\mathbf{0 . 2 0}$ \\
\hline CY & - & - & - & - & - & - & - & 0.11 & & $\mathbf{0 . 1 6}$ \\
\hline FR & 0.09 & 0.09 & 0.10 & 0.09 & 0.10 & 0.09 & - & 0.07 & 0.09 & $\mathbf{0 . 1 3}$ \\
\hline AT & 0.08 & 0.07 & 0.08 & 0.08 & 0.09 & 0.08 & - & 0.07 & 0.10 & $\mathbf{0 . 1 7}$ \\
\hline NL & 0.07 & 0.06 & 0.06 & 0.04 & 0.05 & 0.06 & - & 0.11 & 0.07 & $\mathbf{0 . 1 4}$ \\
\hline SI & - & - & - & - & - & - & - & 0.14 & 0.17 & $\mathbf{0 . 2 0}$ \\
\hline IT & 0.05 & 0.06 & 0.06 & 0.06 & 0.06 & 0.06 & - & 0.09 & 0.07 & $\mathbf{0 . 1 8}$ \\
\hline ES & 0.06 & 0.04 & 0.04 & 0.03 & 0.02 & 0.05 & - & 0.06 & 0.11 & $\mathbf{0 . 1 4}$ \\
\hline HU & 0.07 & 0.06 & - & - & - & - & - & 0.21 & 0.22 & $\mathbf{0 . 1 7}$ \\
\hline DE & 0.06 & 0.06 & 0.06 & 0.07 & 0.07 & 0.06 & - & - & 0.08 & $\mathbf{0 . 1 7}$ \\
\hline PL & - & 0.08 & 0.09 & 0.09 & 0.07 & - & - & 0.14 & 0.22 & $\mathbf{0 . 1 8}$ \\
\hline PT & 0.16 & 0.13 & 0.14 & 0.12 & 0.14 & 0.11 & - & - & 0.16 & $\mathbf{0 . 1 3}$ \\
\hline SK & - & - & - & - & - & - & - & 0.13 & 0.20 & $\mathbf{0 . 2 1}$ \\
\hline EE & - & - & - & - & - & - & - & 0.06 & 0.20 & $\mathbf{0 . 1 4}$ \\
\hline LV & - & - & - & - & - & - & 0.19 & 0.08 & - & $\mathbf{0 . 1 6}$ \\
\hline
\end{tabular}

*Country symbols are as follows: BE - Belgium, FI - Finland, LU - Luxembourg, GR - Greece, IE Ireland, MT - Malta, CY - Cyprus, FR - France, AT - Austria, NL - Netherlands, SI - Slovenia, IT - Italy, ES - Spain, HU - Hungary, DE -Germany, PL - Poland, PT - Portugal, SK - Slovakia, EE - Estonia and LV - Latvia. Source: Boerini and Strauss (2010) for 1996-2001, Romele (2013) for 2010, Psacharopoulos and Patrinos (2018) for 2011, Poteliene and Tamasauskiene (2014) for 2013, and own calculations for the period 2014-2016.

then that the particular IRR approach was founded by DeLaFuente and Jimeno (2009) and then developed by Boerini and Strauss (2010), with some local applications by others (e.g. Romele, 2013) for Latvia. Moreover, a comparable methodology is added from the study of Poteliene and Tamasauskiene (2014) for 2013, where the averages for men and women are shown. The most recent decennial summary by Psacharopoulos and Patrinos (2018) adds mainly 2011 data. Table 1 below compares the available data with the current study estimates

More generally, when inspecting Table 1, which summarizes past research, one may suspect that there is some issue in the comparability of the methodologies. A mutual correlation among countries within a selected year shows stability over time, i.e. developing countries exhibit higher rates than the developed European economies. However, there is no clear trend between years, i.e. it seems as if 
different vintages/authors/methodologies caused incomparability. Therefore, in order to formulate assumptions or theses on the IRR time trends, one should rather stick to a unified methodology/authorship usually applied by international institutions, such as the OECD or the World Bank.

The number of variables, assumptions and calculations applied in this study (see Appendix for details), as compared to the final outcome, i.e. list of numbers (IRR), is quite big and gives an indication of the complexity of this subject. Additionally, there is an ongoing discussion on the adequacy of the Mincerian equation with respect to correctness. Growiec and Groth (2018) claim that a correlation between years of schooling and productivity may be more than nuanced, which suggests that, generally, the IRR results should be taken with caution, especially when applied in the macroeconomic modelling of the semiendogenous growth models. So, to measure the human capital stock in general equilibrium, one should maybe consider lower rates, as suggested by Lucas (1988). In other words, the fact that a subject is well settled in the economic literature does not harden such an approach for ages, since the regularity in the economic data will not always be taken as absolute laws as in physics. This study anyway does not go beyond its main aim and sticks to the classical approach by Mincer (1958).

Since the educational path affects the entire generation's lifespan, the process develops over decades. In the meantime, the older cohorts need to pass a difficult economic transformation into the market economy, so the older cohorts form Central Europe may be barely comparable with those in for instance Western Europe. In order to compare apples to apples, the detailed results and comments are divided into Central-Eastern Europe (CEE: HU, PL, EE, SK, LV, SI) and Western Europe (WE). Few additional, more technical remarks can be derived from Table 1, which are listed below:

- A clear gap in results for the CEE countries may stem for the convergence process, e.g. between 2001 and 2014, the number of persons with higher education grew from $15 \%$ to $43 \%$; in Hungary, it grew from $15 \%$ to $38 \%$.

- In spite of theoretically comparable methodology and sources based on OECD data, the results show high time-series discontinuity.

- $\quad$ The values nearly doubled for the CEE countries and are visibly higher for the WE countries.

- The current study methodology and results show a mixed comparability of IRR's order for the WE countries; however, surprisingly, the calculated values are nearly double those reported by Boerini and Strauss (2010) for the period 1996 - 2001 and Poteliene and Tamasauskiene (2014) for the precedent year, i.e. 2013. 
- The data for the CEE countries shows slightly smaller values than reported by Poteliene and Tamasauskiene (2014), although the order seems quite comparable.

- The reliability of the current study results for the IRR seems more believable for the CEE than for the WE countries. Generally, the current study results show much smaller variance as compared with other studies, which may stem from the consideration of longer periods of time averages for most of the intermediary variables presented in the Appendix.

Despite the applied cost formula, the weaknesses remain nearly the same, from e.g. a lack of inclusion of student loans, missing rental and travelling costs on the one hand to factors such as the following on the other hand: the co-financing of education by external, non-tax sources, the international support or earmarked assets, privatization receipts etc. These weaknesses may be responsible for the differences in theoretically similar countries. Finally, the representative household perspective also equalizes the net rates of return from the given branch of studies, which vary across the educational disciplines by costs (e.g. medicine) or their gross rates of return (e.g. law). However, the applied costs' 'generalization' seems to overcome a problem of the internal financing structure of the education process among countries, especially in terms of rapidly increasing tuition fees in the best universities, which is needed to compute the unified rates of return for taxation purposes.

There might be several reasons for the obtained differences, one of which is the use of the HFCS data for the Mincer equation estimates and gross/net earnings. The application of the 'social' version of the education costs shows little difference, as compared with the corresponding values reported by DeLaFuente and Jimeno (2009) and Romele (2013). More recently, the study of Psacharopoulos and Patrinos (2018) indicates the rates on return, but from different vintages and authors, also for the WE countries.

\section{Conclusions}

The achieved results, ranging between $13 \%$ and $21 \%$, are rather higher than those of Poteliene and Tamasauskiene (2014), although comparable and higher by $\sim 7 \mathrm{pp}$. than historical records for the years 1996-2013. Especially, the most recent decennial summary of Psacharopoulos and Patrinos (2018) shows nearly halved values mostly for 2011, with a quite comparable methodology, which is also applied in a macroeconomic modelling context by Lucas (1988), with a range of $7 \%-10 \%$. Are then current study outcomes believable? On the one hand, for the microeconometric estimate of the Mincer-type equation, they are sound 
and comparable. On the other hand, the methodology that includes pension factors may suggest that a comparison between methodologies may be the key to understand differences among years and authors. Anyway, all in all, an increasing trend in average IRR, in spite of differing authors and methodologies, suggests an increasing trend in valuation and importance of human capital based on high school degree, especially for CEE countries, resulting from rapid economic and cultural convergence. However, their direct use for the macroeconomic models of semi-endogenous growth, which apply the rate of return on investment in education to the life cycle path of wages, seems to yield much too high values.

\section{BibLIOGRAPHY}

D.N. Aspin and J.D. Chapman, 'Lifelong learning: concepts and conceptions'. International Journal of Lifelong Education (2000) vol 21, 535-565.

R. Boerini and H. Strauss, 'What is the Private Return to Tertiary Education? New Evidence from 21 OECD Countries’. OECD Journal: Economic Studies (2010) vol 2010, 25.

A. de la Fuente and F.J. Jimeno, 'The Private and Fiscal Returns to Schooling and the Effect of Public Policies on Private Incentives to Invest in Education: A General Framework and Some Results for the EU'. Banco de España Working Papers (2009) vol 0509.

M. Dziechciarz-Duda and A. Krol, 'An Application of Mincer Model in Analysis of Higher Education Influence on the Wages'. Level, Ekonometria (2012) vol 3, no 37, 56-69.

J.Z. Dziechciarz, 'Measurement of Rate of Return in Education. Research Directions (November 20, 2015)' in Jolán Velencei Ph.D. (ed.), Proceedings of FIKUSZ 2015 (2015), Óbuda University, Budapest, 39-56.

C. Harmon, V. Hogan and I. Walker, 'Dispersion in the Economic Return to Schooling'. Labour Economics (2013) vol 10, no 2, 205-214.

J. Growiec and C. Groth, 'Do Mincerian Wage Equations Inform how Schooling Influences Productivity?’ NBP WP np. 279 (2018).

European Central Bank ECB, 'The Household Finance and Consumption Survey: Results from the Second Wave'. Statistics Paper Series, 2014-2016.

United Nations, 'International Standard Classification of Education - ISCED 2011'. UNESCO Institute for Statistics (2011).

C.I. Jones, 'Source of U.S. Economic Growth in A World of Ideas'. American Economic Review (2002) vol 92, no 1, 220-239.

J. Jabłonowski, 'Implications of Transitory and Permanent Changes in Tax Rates for Poland'. Gospodarka Narodowa (2018) vol 294, 73-97.

R.E. Lucas, 'On the Mechanics of Economic Development'. Journal of Monetary Economy (1988) vol 22, 3-42.

J. Mincer, 'Investment in Human Capital and Personal Income Distribution'. Journal of Political Economy (1958) vol 66, no 4, 281-302.

C.E. Montenegro and H.A. Patrinos, 'Returns to Schooling around the World'. World Development Report (2013). 
OECD, 'Education at a Glance 2018: OECD Indicators'. OECD Publishing, Paris, https:// doi.org/10.1787/eag-2018-en.

S. Poteliene and Z. Tamasauskiene, 'The Rate of Return to Investment in Education: A Case Study of Lithuania Wroclaw Review of Law'. Administration and Economics (2014) vol 4, no 2.

G. Psacharopoulos and H. Patrinos, 'Returns to Investment in Education: A Further Update'. World Bank Policy Research Working Paper (2002) vol 2881.

G. Psacharopoulos and H. Patrinos, 'Returns to Investment in Education, A Decennial Review of the Global Literature'. World Bank Policy Research Working Paper (2018) vol 8402.

S. Rebelo, 'Long-Run Policy Analysis and Long-Run Growth'. Journal of Political Economy (1991) vol 99, 500-521.

L. Romele, 'Estimation of Internal Rate of Return (IRR) to Investments in Education in Latvia'. International Journal of Social Science and Humanity (2013) vol 3, no 1, 1-4.

S. Weber, 'Human Capital Depreciation and Education Level'. International Journal of Manpower (2008) vol 2008, no 5, 613-642.

A. Wolf, A. Jenkins and A. Vignoles, 'Certifying the Workforce: Economic Imperative or Failed Social Policy’. Journal of Education Policy (2006) vol 21, 535-565. 


\section{APPENDIX}

\section{Ancillary Data Used in Calculations}

In line with the main text, the contents are presented in the following order: the Central European Economies (CEE) and then Western Europe (WE). The following tables show the data derived from the Organisation for Economic Cooperation and Development data as of July 2017.

Table A1: Employment and unemployment data, part I

\begin{tabular}{|l|l|l|l|l|l|l|l|l|}
\hline Data & PL $^{5}$ & SK & EE & HU & LV & SI & MT & CY \\
\hline $\begin{array}{l}\text { gross unempl. benefit (\% gross } \\
\text { salary) }\end{array}$ & 0.10 & 0.09 & - & 0.11 & - & - & - & - \\
\hline net unempl. benefit (\% net salary) & 0.21 & 0.22 & 0.23 & 0.17 & 0.24 & 0.25 & - & - \\
\hline gross unempl. benefit (EUR) & 96 & 85 & - & 86 & - & - & - & - \\
\hline net unempl. benefit (EUR) & 106 & 107 & 173 & 62 & 120 & 161 & - & - \\
\hline unempl. rate (tot, av. 2002-2014) & 0.12 & 0.14 & 0.10 & 0.08 & 0.12 & 0.07 & 0.16 & $0.12^{*}$ \\
\hline $\begin{array}{l}\text { empl. rate (tot, av. 2002-2014, \% } \\
\text { work. pop.) }\end{array}$ & 0.57 & 0.59 & 0.66 & 0.57 & 0.63 & 0.65 & 0.58 & $0.60^{*}$ \\
\hline empl. rate (lower sec., 2014) & 0.46 & 0.36 & 0.61 & 0.50 & 0.55 & 0.50 & 0.55 & $0.5^{*}$ \\
\hline empl. rate (upper sec., 2014) & 0.67 & 0.73 & 0.77 & 0.73 & 0.72 & 0.70 & 0.67 & $0.6^{*}$ \\
\hline $\begin{array}{l}\text { empl. rate (Post-sec., non-tert., } \\
\text { 2014) }\end{array}$ & 0.70 & 0.74 & 0.78 & 0.81 & 0.72 & - & - & $0.7^{*}$ \\
\hline empl. rate (Short-cycle tert., 2014) & 0.61 & 0.79 & 0.82 & 0.82 & 0.86 & 0.77 & - & $0.7^{*}$ \\
\hline $\begin{array}{l}\text { empl. rate (Bachelors or equiv., } \\
\text { 2014) }\end{array}$ & 0.83 & 0.73 & 0.87 & 0.80 & 0.84 & 0.86 & - & $0.75^{*}$ \\
\hline empl. rate (Masters or equiv., 2014) & 0.88 & 0.81 & 0.86 & 0.87 & 0.88 & 0.87 & 0.85 & $0.8^{*}$ \\
\hline empl. rate (upper sec., 2014) & 0.95 & 0.85 & 0.89 & 0.89 & 0.93 & 0.92 & 0.85 & $0.8^{*}$ \\
\hline empl. rate (av. w. tert., 2014) & 0.80 & 0.78 & 0.84 & 0.84 & 0.85 & 0.85 & 0.81 & $0.8^{*}$ \\
\hline
\end{tabular}

Source: Own calculations; * means an educated guess. av. = average; empl. = employment; equiv. = equivalent; sec. $=$ secondary; tert. $=$ tertiary; tot $=$ total; unempl. $=$ unemployment; work. pop. $=$ working population, av. w. tert. = average weighted tertiary.

$5 \quad \mathrm{PL}=$ Poland, SK - Slovakia, EE - Estonia, HU - Hungary, LV - Latvia, SI - Slovenia, MT - Malta, CY - Cyprus. 
Table A2: Employment and unemployment data, part II

\begin{tabular}{|c|c|c|c|c|c|c|c|c|c|c|c|c|}
\hline Data & $\mathbf{B E}^{6}$ & FI & DE & FR & NL & ES & IT & AT & PT & IE & GR & $\mathbf{L U}$ \\
\hline $\begin{array}{l}\text { gross unempl. } \\
\text { benefit (\% } \\
\text { gross salary) }\end{array}$ & 0.37 & 0.35 & 0.21 & 0.36 & 0.33 & 0.33 & 0.10 & 0.27 & 0.39 & 0.42 & 0.10 & 0.26 \\
\hline $\begin{array}{l}\text { net unempl. } \\
\text { benefit ( } \% \text { net } \\
\text { salary) }\end{array}$ & 0.62 & 0.49 & 0.41 & 0.49 & 0.38 & 0.39 & 0.23 & 0.52 & 0.43 & 0.58 & 0.21 & 0.30 \\
\hline $\begin{array}{l}\text { gross unempl. } \\
\text { benefit (EUR) }\end{array}$ & 1472 & 1284 & 787 & 1105 & 1382 & 756 & 331 & 1019 & 570 & 1056 & 160 & 1082 \\
\hline $\begin{array}{l}\text { net unempl. } \\
\text { benefit (EUR) }\end{array}$ & 978 & 989 & 693 & 669 & 637 & 415 & 230 & 700 & 290 & 820 & 95 & 919 \\
\hline $\begin{array}{l}\text { unemployment } \\
\text { rate (tot, av. } \\
\text { 2002-2014) }\end{array}$ & 0.08 & 0.08 & 0.08 & 0.09 & 0.05 & 0.16 & 0.09 & 0.04 & 0.10 & 0.09 & 0.16 & 0.04 \\
\hline $\begin{array}{l}\text { (tot, av. 2002- } \\
2014, \% \text { work. } \\
\text { pop.) }\end{array}$ & 0.61 & 0.69 & 0.76 & 0.64 & 0.74 & 0.60 & 0.57 & 0.70 & 0.66 & 0.64 & 0.58 & 0.64 \\
\hline $\begin{array}{l}\text { (lower } \\
\text { secondary, } \\
\text { 2014) }\end{array}$ & 0.53 & 0.58 & 0.62 & 0.61 & 0.64 & 0.57 & 0.54 & 0.54 & 0.74 & 0.65 & 0.61 & 0.79 \\
\hline $\begin{array}{l}\text { (upper } \\
\text { secondary, } \\
\text { 2014) }\end{array}$ & 0.71 & 0.72 & 0.78 & 0.73 & 0.78 & 0.68 & 0.70 & 0.76 & 0.79 & 0.73 & 0.66 & 0.81 \\
\hline $\begin{array}{l}\text { (Post- } \\
\text { secondary, } \\
\text { non-tertiary, } \\
2014 \text { ) }\end{array}$ & 0.83 & 0.94 & 0.85 & 0.59 & 0.88 & 0.62 & 0.74 & 0.80 & 0.83 & 0.86 & 0.67 & 0.83 \\
\hline $\begin{array}{l}\text { (Short-cycle } \\
\text { tertiary, 2014) }\end{array}$ & 0.78 & 0.80 & 0.89 & 0.83 & 0.86 & 0.75 & - & 0.84 & - & 0.76 & 0.79 & - \\
\hline $\begin{array}{l}\text { (Bachelors } \\
\text { or equivalent, } \\
2014 \text { ) }\end{array}$ & 0.84 & 0.82 & 0.88 & 0.82 & 0.87 & 0.78 & 0.69 & 0.77 & 0.74 & 0.76 & 0.67 & 0.87 \\
\hline $\begin{array}{l}\text { (Masters or } \\
\text { equivalent, } \\
\text { 2014) }\end{array}$ & 0.86 & 0.85 & 0.88 & 0.86 & 0.90 & 0.81 & 0.81 & 0.89 & 0.86 & 0.87 & 0.76 & 0.86 \\
\hline $\begin{array}{l}\text { empl. rate } \\
\text { (Doctoral or } \\
\text { equiv., 2014) }\end{array}$ & 0.91 & 0.88 & 0.93 & 0.87 & 0.96 & 0.90 & 0.89 & 0.90 & 0.92 & 0.95 & 0.91 & 0.90 \\
\hline $\begin{array}{l}\text { empl. rate (av. } \\
\text { w. tert.), 2014) }\end{array}$ & 0.84 & 0.86 & 0.89 & 0.79 & 0.89 & 0.77 & 0.78 & 0.84 & 0.84 & 0.81 & 0.73 & 0.83 \\
\hline
\end{tabular}

Source: Own calculations based on Organisation for Economic Co-operation and Development data.av. $=$ average; empl. $=$ employment; tot $=$ total; unempl. $=$ unemployment; work. pop. $=$ working population,, av . w. tert. $=$ average weighted tertiary.

6 BE - Belgium, FI - Finland, DE - Germany, FR - France, NL - Netherlands, ES - Spain, IT - Italy, AT - Austria, PT - Portugal, IE - Ireland, GR - Greece, LU - Luxembourg. 
Table A3: Probability to achieve the degree, part I

\begin{tabular}{|l|l|l|l|l|l|l|l|l|}
\hline Variable & PL & SK & EE & HU & LV & SI & MT & CY \\
\hline Award probability & 0.86 & 0.85 & 0.85 & 0.87 & 0.85 & 0.93 & 0.8 & $0.8^{*}$ \\
\hline
\end{tabular}

Source: Own calculations; * means an educated guess.

Table A4: Probability to achieve the degree, part II

\begin{tabular}{|l|l|l|l|l|l|l|l|l|l|l|l|l|}
\hline Variable & BE & FI & DE & FR & NL & ES & IT & AT & PT & IE & GR & LU \\
\hline award prob. & 0.81 & 0.96 & 0.91 & 0.81 & 0.81 & 0.78 & 0.86 & 0.88 & 0.91 & 0.97 & 0.81 & 0.72 \\
\hline
\end{tabular}

Source: Own calculations based on Organisation for Economic Co-operation and Development data.

Table A5: Marginal tax rates from the Organisation for Economic Co-operation and Development data: gross-gross data, so including employers' wedge, part I

\begin{tabular}{|l|l|l|l|l|l|l|l|l|}
\hline Variable & PL & SK & EE & HU & LV & SI & MT & CY \\
\hline Average labour tax, 2002-14 & 0.39 & 0.46 & 0.43 & 0.67 & - & 0.54 & - & $0.3 *$ \\
\hline
\end{tabular}

Source: Own calculations based on Organisation for Economic Co-operation and Development data.

Table A6: Marginal tax rates from the Organisation for Economic Co-operation and Development data: gross-gross data, so including employers' wedge, part II

\begin{tabular}{|l|l|l|l|l|l|l|l|l|l|l|l|l|}
\hline Variable & BE & FI & DE & FR & NL & ES & IT & AT & PT & IE & GR & LU \\
\hline $\begin{array}{l}\text { Total tax wedge, } \\
\text { average: 2002-14 }\end{array}$ & 0.67 & 0.55 & 0.62 & 0.55 & 0.49 & 0.47 & 0.54 & 0.60 & 0.49 & 0.39 & 0.52 & 0.53 \\
\hline
\end{tabular}

Table A7: Factor productivity, part I

\begin{tabular}{|l|l|l|l|l|l|l|l|l|}
\hline Variable & PL & SK & EE & HU & LV & SI & MT & CY \\
\hline $\begin{array}{l}\text { Labour productivity, average: } \\
\text { 2002-14 }\end{array}$ & 0.027 & 0.032 & 0.030 & 0.026 & 0.040 & 0.018 & 0.01 & $0.01 *$ \\
\hline
\end{tabular}

Source: Own calculations; * means an educated guess. 
Table A8: Factor productivity, part II

\begin{tabular}{|l|l|l|l|l|l|l|l|l|l|l|l|l|}
\hline Variable & BE & FI & DE & FR & NL & ES & IT & AT & PT & IE & GR & LU \\
\hline $\begin{array}{l}\text { Labour } \\
\text { productivity, } \\
\text { average: } \\
\text { 2002-14 }\end{array}$ & 0.008 & 0.009 & 0.01 & 0.08 & 0.09 & 0.010 & 0.001 & 0.011 & 0.010 & 0.04 & 0.00 & 0.04 \\
\hline
\end{tabular}

Source: Own calculations based on Organisation for Economic Co-operation and Development data.

Table A9: Pension system data, part I

\begin{tabular}{|l|l|l|l|l|l|l|l|l|}
\hline Variable & PL & SK & EE & HU & LV & SI & MT & CY \\
\hline $\begin{array}{l}\text { Real pension index., average } \\
\text { 2002-14 }\end{array}$ & 0.05 & 0.06 & 0.08 & 0.08 & 0.06 & 0.08 & 0.03 & 0.03 \\
\hline Retirement age & 62.1 & 61.0 & 63.7 & 62.6 & 63.4 & 62.3 & 59.9 & $60^{*}$ \\
\hline $\begin{array}{l}\text { Life expectancy at birth } \\
\text { (total, 2014) }\end{array}$ & 77.7 & 76.9 & 77.2 & 75.9 & 74.3 & 81.2 & 75 & $75^{*}$ \\
\hline Gross repl. rate (mean) & 0.49 & 0.66 & 0.52 & 0.74 & 0.52 & 0.42 & 0.57 & $0.5^{*}$ \\
\hline Net repl. rate (mean) & 0.59 & 0.85 & 0.62 & 0.95 & 0.68 & 0.63 & 0.70 & $0.7^{*}$ \\
\hline Pension tax rate (mean) & 0.10 & 0.16 & 0.03 & 0.07 & 0.03 & 0 & 0.10 & $0.10^{*}$ \\
\hline
\end{tabular}

Source: Own calculations; $*$ means an educated guess, repl. = replacement.

Table A10: Pension system data, part II

\begin{tabular}{|l|l|l|l|l|l|l|l|l|l|l|l|l|}
\hline Variable & BE & FI & DE & FR & NL & ES & IT & AT & PT & IE & GR & LU \\
\hline $\begin{array}{l}\text { Real pension } \\
\text { index., average } \\
\text { 2002-14 }\end{array}$ & 0.03 & 0.03 & 0.03 & 0.03 & 0.03 & 0.02 & 0.03 & 0.03 & 0.02 & 0.03 & 0.03 & 0.03 \\
\hline Retirement age & 59.9 & 61.9 & 62.7 & 59.3 & 62.9 & 62.2 & 61.4 & 62.2 & 67.0 & 65.3 & 61.5 & 61.9 \\
\hline $\begin{array}{l}\text { Life expectancy } \\
\text { at birth (total, } \\
\text { 2014) }\end{array}$ & 81.4 & 81.3 & 81.2 & 82.8 & 81.8 & 83.3 & 83.2 & 81.6 & 81.2 & 81.4 & 81.5 & 82.3 \\
\hline Gross repl. rate & 0.41 & 0.55 & 0.42 & 0.59 & 0.91 & 0.74 & 0.71 & 0.77 & 0.55 & 0.37 & 0.54 & 0.56 \\
\hline Net repl. rate & 0.62 & 0.63 & 0.57 & 0.71 & 1 & 0.80 & 0.81 & 0.90 & 0.68 & 0.45 & 0.70 & 0.69 \\
\hline Pension tax rate & 0.06 & 0.16 & 0.10 & 0.11 & 0.27 & 0.16 & 0.20 & 0.17 & 0.09 & 0.11 & 0.13 & 0.09 \\
\hline
\end{tabular}

Source: Own calculations based on Organisation for Economic Co-operation and Development data. 
Table A11: Schooling and studying data, part I

\begin{tabular}{|l|l|l|l|l|l|l|l|l|}
\hline Variable & PL & SK & EE & HU & LV & SI & MT & CY \\
\hline $\begin{array}{l}\text { Age at start of schooling, } \\
2014\end{array}$ & 7 & 6 & 7 & 7 & 7 & 6 & 5 & $6^{*}$ \\
\hline Schooling years, 2014 & 11.8 & 12.4 & 12.0 & 11.3 & 11.5 & 11.9 & 9.9 & \\
\hline $\begin{array}{l}\text { World Bank estimated years } \\
\text { in school }\end{array}$ & 12.2 & 12.4 & 12.9 & 11.5 & 12.6 & 12.1 & 10.0 & $11^{*}$ \\
\hline $\begin{array}{l}\text { Costs per student } \\
\text { (thousand EUR./y, average) }\end{array}$ & 6.7 & 7.8 & 8.7 & 7.5 & 6.2 & 9.1 & 8.4 & $8^{*}$ \\
\hline $\begin{array}{l}\text { Number of students } \\
\text { (total, average, thousands) }\end{array}$ & 1777.1 & 197.2 & 60.0 & 332.1 & 90.0 & 91.3 & 12.8 & $11^{*}$ \\
\hline
\end{tabular}

Source: Own calculations based on Organisation for Economic Co-operation and Development data.

Table A12: Schooling and studying, part II

\begin{tabular}{|l|l|l|l|l|l|l|l|l|l|l|l|l|}
\hline Variable & BE & FI & DE & FR & NL & ES & IT & AT & PT & IE & GR & LU \\
\hline $\begin{array}{l}\text { Age at } \\
\text { start of } \\
\text { schooling, } \\
2014\end{array}$ & 6 & 7 & 6 & 6 & 6 & 6 & 6 & 6 & 6 & 5 & 6 & 6 \\
\hline $\begin{array}{l}\text { Schooling } \\
\text { years, 2014 }\end{array}$ & 10.9 & 10.3 & 12.9 & 11.1 & 11.9 & 9.6 & 10.1 & 10.8 & 8.2 & 11.6 & 10.2 & 11.3 \\
\hline $\begin{array}{l}\text { WB } \\
\text { estimated } \\
\text { years in } \\
\text { school }\end{array}$ & 11.9 & 14.2 & 13.9 & 10.9 & 11.7 & 9.5 & 10.2 & 12.3 & 7.8 & 12.5 & 10.7 & 11.6 \\
\hline $\begin{array}{l}\text { Annual } \\
\text { costs per } \\
\text { student } \\
\text { (thousand } \\
\text { EUR) }\end{array}$ & 11.9 & 13.5 & 12.7 & 12.2 & 14.3 & 9.5 & 8.4 & 12.6 & 8.4 & 10.3 & 8.4 & 30.8 \\
\hline $\begin{array}{l}\text { Number of } \\
\text { students } \\
\text { thousands }\end{array}$ & 496.4 & 305.9 & 2890.0 & 2383.7 & 842.6 & 1971.8 & 1863.5 & 423.3 & 356.9 & 201.7 & 677.4 & 6.9 \\
\hline
\end{tabular}

Source: Own calculations based on Organisation for Economic Co-operation and Development data. 
Table A13: Internal rate of return data, part I

\begin{tabular}{|l|l|l|l|l|l|l|l|l|}
\hline Variable $^{7}$ & PL & SK & EE & HU & LV & SI & MT & CY \\
\hline$\tau_{0}$ & 0.39 & 0.41 & 0.40 & 0.47 & 0.44 & 0.43 & 0.29 & $0.3^{*}$ \\
\hline$\tau_{u n}$ & 0 & 0 & 0.15 & 0.27 & 0.24 & 0 & 0.10 & $0.1^{*}$ \\
\hline$\tau$ & 0.22 & 0.24 & 0.28 & 0.29 & 0.31 & 0.28 & 0.29 & $0.3^{*}$ \\
\hline$\%$ & 0.57 & 0.54 & 0.69 & 0.61 & 0.63 & 0.60 & 0.66 & $0.6^{*}$ \\
\hline$p_{h i}$ & 0.80 & 0.78 & 0.84 & 0.83 & 0.85 & 0.85 & 0.84 & $0.8^{*}$ \\
\hline$p_{s e c}$ & 0.14 & 0.14 & 0.12 & 0.14 & 0.13 & 0.14 & 0.13 & $0.12^{*}$ \\
\hline$\Xi$ & 0.86 & 0.85 & 0.85 & 0.87 & 0.85 & 0.93 & 0.80 & $0.8^{*}$ \\
\hline$\tau_{\Delta}$ & 0.15 & 0.11 & 0.14 & 0.16 & 0.19 & 0.18 & 0.10 & $0.1 *$ \\
\hline$\Theta$ & 0.13 & 0.14 & 0.09 & 0.13 & 0.14 & 0.17 & 0.20 & $0.2^{*}$ \\
\hline$v$ & 0.0004 & 0.0002 & 0.0001 & 0.0003 & 0.0002 & 0.0003 & 0.0001 & $0.0001^{*}$ \\
\hline$P_{n}$ & 0.01 & 0.09 & 0.08 & 0.09 & 0.08 & 0.09 & 0.08 & $0.06^{*}$ \\
\hline$\Theta{ }_{n}$ & 0.06 & 0.01 & 0.00 & 0.01 & 0.01 & 0.01 & 0.01 & $0.01^{*}$ \\
\hline$g$ & 0.027 & 0.032 & 0.030 & 0.026 & 0.040 & 0.018 & 0.011 & $0.010^{*}$ \\
\hline$\varpi$ & 0.06 & 0.08 & 0.07 & 0.06 & 0.08 & 0.03 & $0.04^{*}$ \\
\hline$L E$ & 77.7 & 76.9 & 77.2 & 75.9 & 74.3 & 81.2 & 75 & $75^{*}$ \\
\hline
\end{tabular}

$7 \quad \tau_{0}=$ average labour-time gross tax rate on earnings, $\tau_{u n}=$ tax rate for the unemployment benefits, $\tau$ = average lifetime gross tax rate, $\delta-, p_{h i}$ - average employment rate of higlier education-level student, $p_{\text {sec }}$-average employment rate of secondary education-level, $p$ average weighted employment rate for secondary and tertiary levels, $\Xi$ - survival rate for higher education students, $\tau_{\Delta}$ - marginal tax rate for a person in a reference group, $\Theta$ means a wage premium for each year of tertiary education, $v$-return on experience in the Mincerian equation, $P_{n}$ - net income, $\Theta_{n}$ net wage premium for each year of tertiary education, $g$ - growth in labour productivity over the past decade, $\varpi$ - real growth rate 8 of pensions, $L E$ - life expectancy at birth, $R R$ - pension benefit replacement rate. Further, $p$ employment probability for people with upper secondary education, $Y$ - length of the working period, $A g e_{0}$ - age at which\%school education starts, $R A$ - effective retirement age, $\tilde{n}_{R}$ pension premium factor, $P C$ - direct private cost of tertiary education, expressed as a percentage of the average wage, $\mathrm{Y}_{0}$ - secondary education graduates. $O P P C$ - opportunity cost of schooling, DIRC - direct costs of schooling, IRR - internal rate of return on higher education. 


\begin{tabular}{|l|l|l|l|l|l|l|l|l|}
\hline Variable $^{7}$ & PL & SK & EE & HU & LV & SI & MT & CY \\
\hline$R A$ & 62.1 & 61.1 & 63.7 & 62.6 & 63.4 & 62.3 & 59.9 & $60^{*}$ \\
\hline$R$ & -0.014 & -0.017 & -0.021 & -0.013 & -0.026 & 0.005 & 0.01 & $0.01^{*}$ \\
\hline $\mathrm{Y}$ & 43.3 & 42.7 & 44.7 & 44.3 & 44.9 & 44.4 & 40.1 & $40^{*}$ \\
\hline$\tau_{v}$ & 0.10 & 0.16 & 0.03 & 0.07 & 0.03 & 0.9 & 0.11 & $0.10^{*}$ \\
\hline$R R$ & 0.59 & 0.85 & 0.62 & 0.95 & 0.68 & 0.65 & 0.70 & $0.50^{*}$ \\
\hline$\tilde{n}_{R}$ & 0.0040 & 0.0071 & 0.0035 & 0.0062 & 0.0084 & 0.0021 & 0.005 & 0.0032 \\
\hline \begin{tabular}{l} 
\% \\
\hline $\mathrm{Y}_{0}$
\end{tabular} & 0.013 & 0.088 & 0.142 & 0.123 & 0.091 & 0.182 & 0.121 & 0.111 \\
\hline OPPC & 0.44 & 0.41 & 0.49 & 0.43 & 0.44 & 0.48 & 0.49 & 0.50 \\
\hline$D I R C$ & 0.12 & 0.10 & 0.10 & 0.14 & 0.10 & 0.11 & 0.18 & 0.15 \\
\hline$I R R$ & 0.18 & 0.21 & 0.14 & 0.17 & 0.16 & 0.20 & 0.15 & 0.14 \\
\hline
\end{tabular}

Source: Own calculations; * means an educated guess.

Table A14: Internal rate of return data, part II

\begin{tabular}{|l|l|l|l|l|l|l|l|l|l|l|l|l|}
\hline $\begin{array}{l}\text { Varia- } \\
\text { ble }\end{array}$ & BE & FI & DE & FR & NL & ES & IT & AT & PT & IE & GR & LU \\
\hline $\begin{array}{l}\tau_{0} \\
(=\tau)\end{array}$ & 0.56 & 0.51 & 0.43 & 0.48 & 0.42 & 0.45 & 0.56 & 0.51 & 0.55 & 0.43 & 0.54 & 0.38 \\
\hline$\tau_{u n}$ & 0.33 & 0.23 & 0.11 & 0.39 & 0.54 & 0.45 & 0.30 & 0.22 & 0.49 & 0 & 0 & 0.15 \\
\hline$\tau$ & 0.37 & 0.37 & 0.31 & 0.34 & 0.33 & 0.34 & 0.34 & 0.37 & 0.41 & 0.42 & 0.32 & 0.26 \\
\hline$\%$ & 0.63 & 0.65 & 0.70 & 0.67 & 0.71 & 0.63 & 0.62 & 0.65 & 0.76 & 0.61 & 0.55 & 0.68 \\
\hline$p$ & 0.85 & 0.86 & 0.87 & 0.79 & 0.89 & 0.77 & 0.78 & 0.84 & 0.84 & 0.81 & 0.73 & 0.83 \\
\hline$p_{h i}$ & 0.13 & 0.13 & 0.12 & 0.11 & 0.12 & 0.12 & 0.13 & 0.29 & 0.10 & 0.13 & 0.13 & 0.12 \\
\hline$\Xi$ & 0.81 & 0.96 & 0.91 & 0.81 & 0.81 & 0.78 & 0.86 & 0.88 & 0.91 & 0.97 & 0.81 & 0.71 \\
\hline$\tau_{\Delta}$ & 0.23 & 0.20 & 0.19 & 0.25 & 0.27 & 0.13 & 0.16 & 0.27 & 0.18 & 0.09 & 0.11 & 0.17 \\
\hline$v$ & 0.0002 & 0.0002 & 0.0007 & 0.0004 & 0.0002 & 0.0002 & 0.0001 & 0.0001 & 0.0001 & 0.0001 & 0.0001 & 0.00001 \\
\hline
\end{tabular}




\begin{tabular}{|l|l|l|l|l|l|l|l|l|l|l|l|l|}
\hline $\begin{array}{l}\text { Varia- } \\
\text { ble }\end{array}$ & BE & FI & DE & FR & NL & ES & IT & AT & PT & IE & GR & LU \\
\hline$P_{n}$ & 0.074 & 0.051 & 0.081 & 0.080 & 0.066 & 0.068 & 0.069 & 0.072 & 0.061 & 0.11 & 0.073 & 0.064 \\
\hline$\Theta_{n}$ & 0.002 & 0.004 & 0.006 & 0.002 & 0.007 & 0.005 & 0.011 & 0.005 & 0.008 & 0.007 & 0.008 & 0.006 \\
\hline$\%$ & 0.008 & 0.008 & 0.013 & 0.081 & 0.092 & 0.011 & 0.001 & 0.011 & 0.0102 & 0.038 & 0.001 & 0.004 \\
\hline$g$ & 0.03 & 0.03 & 0.03 & 0.03 & 0.03 & 0.02 & 0.01 & 0.03 & 0.02 & 0.03 & 0.03 & 0.03 \\
\hline$L E$ & 81.4 & 81.3 & 81.2 & 82.8 & 81.8 & 83.3 & 83.2 & 81.6 & 81.2 & 81.3 & 81.5 & 82.3 \\
\hline$R A$ & 59.9 & 61.9 & 62.7 & 59.4 & 62.9 & 62.2 & 61.4 & 62.2 & 67.0 & 65.4 & 61.5 & 61.9 \\
\hline $\mathrm{Y}$ & 43.0 & 44.6 & 43.8 & 42.3 & 45.0 & 46.6 & 45.3 & 45.4 & 52.8 & 48.8 & 45.4 & 44.6 \\
\hline$\tau_{v}$ & 0.06 & 0.16 & 0.11 & 0.11 & 0.27 & 0.16 & 0.20 & 0.17 & 0.10 & 0.11 & 0.13 & 0.09 \\
\hline$R R$ & 0.62 & 0.63 & 0.57 & 0.71 & 1 & 0.80 & 0.81 & 0.90 & 0.68 & 0.45 & 0.70 & 0.69 \\
\hline$\tilde{n}_{R}$ & 0.0003 & 0.0025 & 0.0029 & 0.0016 & 0.0040 & 0.0002 & 0.0039 & 0.0040 & 0.0020 & 0.0031 & 0.0032 & 0.002 \\
\hline \begin{tabular}{l}
$\%$ \\
\hline$P$
\end{tabular} & 0.013 & 0.028 & 0.003 & 0.006 & 0.027 & 0.010 & 0.003 & 0.023 & 0.166 & 0.043 & 0.18 & 0.02 \\
\hline $\mathrm{Y}{ }_{0}$ & 42.1 & 40.1 & 42.8 & 42.5 & 45.2 & 46.7 & 45.2 & 43.9 & 53.2 & 47.6 & 44.9 & 44.3 \\
\hline$O P P C$ & 0.41 & 0.42 & 0.49 & 0.46 & 0.48 & 0.45 & 0.43 & 0.41 & 0.48 & 0.55 & 0.37 & 0.50 \\
\hline$D I R C$ & 0.07 & 0.07 & 0.05 & 0.07 & 0.03 & 0.09 & 0.06 & 0.07 & 0.08 & 0.04 & 0.18 & 0.02 \\
\hline$I R R$ & 0.17 & 0.18 & 0.17 & 0.13 & 0.11 & 0.14 & 0.18 & 0.18 & 0.13 & 0.21 & 0.15 & 0.14 \\
\hline
\end{tabular}

Source: Own calculations. 